\title{
Opuntia dillenii: A Forgotten Plant with Promising Pharmacological Properties
}

\author{
Reza Shirazinia ${ }^{1 \dagger}$, Vafa Baradaran Rahimi ${ }^{2,3+}$, Ashrafali Rezaie Kehkhaie ${ }^{1}$, \\ Amirhossein Sahebkar ${ }^{4}$, Hassan Rakhshandeh ${ }^{2,3}$, Vahid Reza Askari ${ }^{2,3,4 *}$ \\ 'Department of Pharmacology, Faculty of Veterinary Medicine, University of Tehran, Tehran, Iran \\ ${ }^{2}$ Student Research Committee, Department of Pharmacology, Faculty of Medicine, Mashhad University of Medical Sciences, Mashhad, Iran \\ ${ }^{3}$ Pharmacological Research Center of Medicinal Plants, Mashhad University of Medical Sciences, Mashhad, Iran \\ ${ }^{4}$ Neurogenic Inflammation Research Center, Mashhad University of Medical Sciences, Mashhad, Iran
}

\section{Key Words}

Opuntia dillenii, anti-oxidant, immuno-modulation, neuro-protection, pharmacological activity, anti-tumor

\section{List of abbreviation \\ ALT: Alanine transaminase \\ AST: Aspartate transaminase \\ DDPH: 2,2-diphenyl-1-picrylhydrazyl \\ GR: glucocorticoid receptor \\ GSH: Glutathione \\ GSH-PX: Glutathione peroxidase \\ GST: Glutathione S-transferases \\ Ip: intraperitoneal \\ MDA: Malondialdehyde \\ Opuntia dillenii (OD) \\ ODT: OD tablet \\ RSM: Response surface methodology}

\begin{abstract}
Generative and vegetative parts of the cactuses have had a long-lasting position in folk medicine and their effects could partly be confirmed in scientific experiments. Nowadays, the cactus, fruits, and cladodes are the focus of many studies because of their desirable properties. Therefore, the summarized reports of valu-
\end{abstract}

Received: Oct 25, 2018 Reviewed: Nov 06, 2018 Accepted: Feb 11, 2019

(c) This is an Open-Access article distributed under the terms of the Creative Common Attribution Non-Commercial License (http://creativecommons.org/licenses/by-nc/4.0/) which permits unrestricted noncommercial use, distribution, and reproduction in an medium, provided the original work is properly cited.

(2) This paper meets the requirements of KS X ISO 9706, ISO 9706-1994 and ANSI/NISO Z39.48-1992 (Permanence of Paper). able properties of medicinal plants may be a good way to familiarize researches with a new source of drugs with lower side effects and higher efficacy.

Opuntia dillenii, a well-known member of the Cactaceae family, is used as a medicinal plant in various countries and grows in the desert, semi-desert, tropical and sub-tropical areas. It shows diverse pharmacological activities such as: antioxidant, anti-inflammatory, anti-tumor, neuroprotective, hepatoprotective, hypotensive etc. $O D$ fruit also possesses valuable constitutes for instance: betalains, ascorbic acid, total phenol, protein as well as essential elements which suggest the significant potential of this plant as a complementary therapy against several pathological conditions. This review describes experimental evidence about pharmacological and therapeutic potential of $O D$ in order to give the basis of its application in the prevention and treatment of some chronic diseases. More studies on $O D$ can help better understanding of its pharmacological mechanism of action to explain its traditional uses and to identify its potential new therapeutic applications.

\section{Introduction}

From ancient times, in search for rescue from diseases, the people are looking for drugs in natural environments. The onset of the medicinal plants' use was instinctive and there was not enough information about the reasons for the illnesses and how plants could be utilized as a cure [1]. The genesis of iatrochemistry in
"Corresponding Author

Vahid Reza Askari. Pharmacological Research Center of Medicinal Plants, Mashhad University of Medical Sciences, Mashhad, Iran.

Tel: +98-513-800-2262 Fax: +98-513-882-8564

E-mail: askariv941@mums.ac.ir, vahidrezaaskary@yahoo.com

$\dagger$ The authors had an equal contribution as the first author.

(c) 2019 Korean Pharmacopuncture Institute 
the 16th century was the start of using plants as a source for treatment and prophylaxis of diseases [2]. Nowadays, it is reported that about 2000 medicinal plant groups exist throughout the world, each one has its unique clinical value or chemical compositions [3, 4]. Plants have received great attention in developed countries as valuable compounds with acceptable efficacy and safety in treating different diseases. It has been reported that more than 3.3 billion people in the low-population countries use medicinal plant on a regular basis [5]. An estimation by the world health organization (WHO) showed that about $80 \%$ of African people rely on herbal medicines for the treatment of many diseases [6]. Nowadays many pieces of research have revealed side effects of chemical drugs and this made many people notice the medicinal plants chemical drugs. Developed side effects even may show up at their right dose as well as in combination with other drugs. Drugs adverse effects impress about 2 million patients in the United States annually and cause an approximately 100,000 deaths. In this regard, the exhibition of severe adverse effects made US Food and Drug Administration advisory panel to ban the popular pain relievers Percocet and Vicodin $[7,8]$. In this context, it made researches all around the world to conduct various researches in the topics of medicinal plants among these researches, review studies expressing the value and importance of specific herbal products play vital roles.

Opuntia dillenii $(O D)$ a plant form Cactacea growing in dry and desert environments is a great medicinal herb, a shrub grows in desert and dry conditions with a height of about 1 to 1.8 meters [24]. Additionally, $O D$ has very beautiful flowers with amazing coloration due to betalain and possess important chemicals including betanin, polysaccharide composition of galactose and arabinose, 3-O-methyl quercetin, kaempferide, kaempferol, isorhamnetin, quercetin, beta- sitosterol, 4-ethoxy-6-hydroxymethyl-alpha-pyrone, opuntisterol, opuntisteroside, taraxerol, friedelin, methyl linoleate, 7 -oxositosterol, 6 - $\beta$-hydroxystigmast4-ene-3-one,daucosterol, eucomic acid, methyl eucomate and also with moisture, protein, brix, acidity, glucose, fructose, saccharose and minerals. The species $O D$, Nagphana, is not much explored while its protective effects have so far been reported including analgesic, anti-inflammatory [9], radical scavenging activity [10] and anti-spermatogenic effect [11] as well as especially known as an anti-diabetic and anti-inflammatory agent from past decades [12, 13]. Regarding the traditional uses, it has been suggested that the fruit of $O D$ may be useful as a medication for gonorrhea, whooping cough and constipation, as well as controlling the bile secretion, spasmodic cough and expectoration. Additionally, leaves of the plant have been applied as a medication for the wound and inflammation as well as a treatment for ophthalmic disorders $[12,14]$.

On this basis, the aim of the present study is to summarize the valid data on $O D$ and its chemical composition and potential pharmacologic properties to have a better insight on the position of $O D$ among various medicinal plants and its further potential application (Table 1).

Table 1 Summarization of pharmacological properties of $O D$

\begin{tabular}{|c|c|c|c|}
\hline Pharmacologic effect & Model & Measurements & Evidence \\
\hline Anti-inflammation & $\begin{array}{c}\text { carrageenan-induced paw ede- } \\
\text { ma in rats }\end{array}$ & Percentages of edema & $\begin{array}{l}\text { Reduction of edema percent- } \\
\text { age based on the dose- related } \\
\text { manner [9]. }\end{array}$ \\
\hline Anti-inflammation & $\begin{array}{l}\text { carrageenan-induced paw ede- } \\
\text { ma in rats }\end{array}$ & Percentages of edema & $\begin{array}{l}\text { The most anti-inflammatory } \\
\text { effect for the flower extraction at a } \\
\text { dose of } 200 \mathrm{mg} / \mathrm{kg} \mathrm{[48].}\end{array}$ \\
\hline Anti-inflammation & $\begin{array}{c}\text { arachidonic acid(AA) and 12-O- } \\
\text { tetradecanoyl-phorbol- 13-acetate } \\
\text { (TPA) ear edema of mice- phos- } \\
\text { pholipase A2 (PLA2)-induced } \\
\text { mice paw edema Carrageenan and } \\
\text { glycogen- induced peritonitis in } \\
\text { rodents }\end{array}$ & $\begin{array}{c}\text { leukotriene B4 (LTB4)- reactive } \\
\text { oxygen species (ROS)- prostaglan- } \\
\text { din E2 (PGE2)-tumor necrosis } \\
\text { factor (TNF- } \alpha \text { ) interleukins (IL-1 } \beta \\
\text { IL- } 6 \text { ) }\end{array}$ & $\begin{array}{c}\text { Reduction of AA and TPA } \\
\text { induced ear punch to weigh in a } \\
\text { dose-dependent manner- Attenu- } \\
\text { ation of paw edema and peritoni- } \\
\text { tis-reduction of PGE2, LTB4, ROS } \\
\text { and cytokine levels (TNF- } \alpha \text {, IL-1ß } \\
\text { IL -6) [26]. }\end{array}$ \\
\hline Immunomodulatory effect & $\begin{array}{l}\text { Murine immunosuppressed by } \\
\text { intraperitoneal injection of cyclo- } \\
\text { phosphamide (Cy, ip). }\end{array}$ & $\begin{array}{c}\text { Intraserous hemolysin IgM, } \\
\text { IgG levels- the proliferation of } \\
\text { splenocytes - the proportion of T } \\
\text { lymphocyte subsets in peripheral } \\
\text { blood- main component purified } \\
\text { from OD polysaccharides on the } \\
\text { lymphocytes in vitro }\end{array}$ & $\begin{array}{l}\text { OD can potentially enhance } \\
\text { the specific immune function of } \\
\text { immunosuppressed mice and the } \\
\text { proliferation of lymphocytes [86]. }\end{array}$ \\
\hline Antioxidant & DHPP assay & $\begin{array}{l}\text { DPPH free radical scavenging } \\
\text { activity }\end{array}$ & $\begin{array}{c}\text { IC50 for scavenging activity on } \\
\text { DPPH free radical was decreasing } \\
\text { by the increment of } O D \text { extract } \\
\text { purity [54]. }\end{array}$ \\
\hline Antioxidant & DHPP assay & $\begin{array}{l}\text { DPPH free radical scavenging } \\
\text { activity }\end{array}$ & $\begin{array}{l}\text { DPPH radical scavenging activi- } \\
\text { ties of the 3,4-dihydroxy substitut- } \\
\text { ed flavonoids (such as quercetin) } \\
\text { were stronger than those of the } \\
\text { 4-hydroxyl substitutes (such as } \\
\text { kaempferol) [56]. }\end{array}$ \\
\hline Antioxidant & $\begin{array}{l}\text { DPPH test, hydroxyl radicals, and } \\
\text { superoxide radical in vitro }\end{array}$ & $\begin{array}{l}\mathrm{DPPH} \text {, hydroxyl and superoxide } \\
\text { radicals scavenging. }\end{array}$ & $\begin{array}{l}\text { 2-4 month-old } O D \text { had higher } \\
\text { antioxidant activity than 5-10 } \\
\text { month-old } O D \text { and a fraction } \\
\text { isolated from } O D \text { (ODP-Ia) was } \\
\text { superior to 5-10 month } O D \text { [57]. }\end{array}$ \\
\hline
\end{tabular}




\begin{tabular}{|c|c|c|c|}
\hline Pharmacologic effect & Model & Measurements & Evidence \\
\hline Antioxidant & $\begin{array}{l}\text { On the basis of the ability to } \\
\text { scavenge the } \mathrm{ABTS}^{+} \text {radical in vitro } \\
\text { Folin-Ciocalteau reaction }\end{array}$ & $\begin{array}{l}\text { Measurement of ABTS } \text { Aree }^{+} \\
\text {radical And Folin-Ciocalteau } \\
\text { reduction capacity (FCRC) }\end{array}$ & $\begin{array}{c}\text { The antioxidant activity of ex- } \\
\text { tracts of OD fruit was based in the } \\
\text { bottom order (crude extract (CE) }> \\
\text { purified extract }(\mathrm{PE})>\text { red fraction } \\
(\mathrm{RF})>\text { yellow fraction }(\mathrm{YF}) \text { in con- } \\
\text { cordance with the (FCRC) }[31] \text {. }\end{array}$ \\
\hline Antioxidant & $\begin{array}{l}\text { Oxygen radical absorbance } \\
\text { capacity (ORAC) assay }\end{array}$ & $\begin{array}{l}\text { Measurement of the ability of } \\
\text { antioxidant components in test } \\
\text { materials to inhibit the decline } \\
\text { in R-PE fluorescence induced by } \\
\text { a peroxyl radical generator R-PE } \\
\text { fluorescence that is induced by a } \\
\text { peroxyl radical generator, AAPH. }\end{array}$ & $\begin{array}{l}\text { The varieties with red-skin fruits } \\
\text { (O. streptacantha) contained the } \\
\text { most ascorbic acid and the yel- } \\
\text { low-skinned fruits (Opuntia stricta } \\
\text { var. stricta) had the most carot- } \\
\text { enoids. Relation of antioxidant } \\
\text { activity to their flavonoid, ascorbic } \\
\text { acid and carotenoid contents [58]. }\end{array}$ \\
\hline Antioxidant & $\begin{array}{c}\text { TEAC assay - Oxygen-radical } \\
\text { absorbance capacity assay (ORAC) } \\
\text { (Clinical trial) }\end{array}$ & \begin{tabular}{|c|} 
Trolox equivalent antioxidant ca- \\
pacity (TEAC) assay as described \\
by Miller, Rice-Evans, Davies, \\
Gopinathan, and Milner [87]-Ox- \\
ygen- radical absorbance capacity \\
assay (ORAC) assay was based on \\
the report by Cao, Sofic, and Prior \\
[88] with a slight modification \\
\end{tabular} & \begin{tabular}{|c|} 
Higher antioxidant capacity for \\
betacyanin-free seeds of $O D$ than \\
extracts from peel and pulp with \\
betacyanins [43].
\end{tabular} \\
\hline Neuro-protective & $\begin{array}{l}\text { Brain ischemia- reperfusion inju- } \\
\text { ry in rats-the oxidative stress-in- } \\
\text { duced damage in PC12 cells }\end{array}$ & $\begin{array}{c}\text { Neurological deficit score- in- } \\
\text { farct volume- neuronal loss in the } \\
\text { cerebral cortex- protein synthesis } \\
\text { of inducible nitric oxide synthase- } \\
\text { cell viability- } \mathrm{H}_{2} \mathrm{O}_{2} \text { induced apop- } \\
\text { tosis-both intracellular and total } \\
\text { accumulation of reactive oxygen } \\
\text { species (ROS) production- Bax/ } \\
\text { Bcl-2 mRNA ratio }\end{array}$ & \begin{tabular}{|} 
Cactus polysaccharides $(200 \mathrm{mg} /$ \\
$\mathrm{kg}$ ) significantly decreased the \\
neurological deficit score, reduced \\
infarct volume, decreased neu- \\
ronal loss in cerebral cortex, and \\
also reduced the protein synthesis \\
of iNOS- protection of PC12 cells \\
against hydrogen peroxide $\left(\mathrm{H}_{2} \mathrm{O}_{2}\right)$ \\
destruction- elevation of cell via- \\
bility, reduction of $\mathrm{H}_{2} \mathrm{O}_{2}$ induced \\
apoptosis decrement both intra- \\
cellular and total accumulation \\
of reactive oxygen species (ROS) \\
production, upregulation of Bax/ \\
Bcl-2 mRNA ratio[65]. \\
\end{tabular} \\
\hline Anti-diabetic effect & $\begin{array}{l}\text { Normoglycemic and alloxan-in- } \\
\text { duced diabetes rabbits }\end{array}$ & $\begin{array}{c}\begin{array}{c}\text { Plasma insulin levels blood } \\
\text { glucose levels }\end{array} \\
\end{array}$ & $\begin{array}{c}\text { Hypoglycemic effect of this plant } \\
\text { partly due to reducing intestinal } \\
\text { absorption of glucose [42]. }\end{array}$ \\
\hline Anti-diabetic effect & $\begin{array}{l}46 \text { type } 2 \text { diabetes mellitus (DM) } \\
\text { patients (clinical trial) }\end{array}$ & \begin{tabular}{|c|} 
Observation of symptoms- deter- \\
mination of FBG, PBG and 24 hrs \\
urinary sugar - glycosylated he- \\
moglobin- fasting insulin (FINS), \\
2 hrs post-meal insulin (PINS) \\
and glucagons (GC)- sensitivity of \\
insulin (SI)- Serum $\mathrm{B}_{2}$ micro-glob- \\
ulin (SB - MG)-urinary B2 micro- \\
globulin (U-B $\mathrm{B}_{2}$-MG)- serum \\
Tamm-Horsfall (S-THP)- urinary \\
Tamm-Horsfall (U- THP)-serum \\
endothelin (S-ET) and urinary \\
endothelin (U-ET)- micro-al- \\
bumin (MA)- $\alpha$ micro-globulin \\
(a-MG)- transferrin (TRF) - IgG \\
and plasma NO \\
\end{tabular} & \begin{tabular}{|c} 
Improve the glycometabolism of \\
DM patients sufficiently and avoid \\
the impairment of renal function \\
in diabetic neuropathy [83].
\end{tabular} \\
\hline Anti-diabetic effect & $\begin{array}{l}\text { Streptozotocin (STZ)- induced } \\
\text { diabetes in rats }\end{array}$ & \begin{tabular}{|c|} 
Body weight gain\%- blood glu- \\
cose concentration liver glycogen \\
content- lipid peroxide (MDA) \\
level- total cholesterol (TC), \\
triacylglycerols (TAG), low-density \\
lipoprotein cholesterol (LDL-C) \\
and very low-density lipoprotein \\
cholesterol (VLDL-C) high-density \\
lipoprotein cholesterol (HDL-C) \\
\end{tabular} & $\begin{array}{l}\text { Administration of OD juice to } \\
\text { diabetic rats significantly improve } \\
\text { lipid profile and body weight gain } \\
\% \text {, it also significantly reduced } \\
\text { MDA levels and blood glucose } \\
\text { [84]. }\end{array}$ \\
\hline Anti-diabetic effect & $\begin{array}{l}\text { Streptozotocin (STZ)- induced } \\
\text { diabetes in mice }\end{array}$ & Blood glucose & $\begin{array}{c}\text { The results show that OD Haw. } \\
\text { polysaccharides have hypoglyce- } \\
\text { mic activity [89]. }\end{array}$ \\
\hline Analgesic & $\begin{array}{l}\text { Hotplate and writhing test in rat } \\
\text { and mice }\end{array}$ & $\begin{array}{l}\text { Number of writhing movements } \\
\text { and Reaction time }\end{array}$ & $\begin{array}{c}\text { The increment of the reaction } \\
\text { time of rats from the dose } 100 \\
\text { mg/kg and reduction of writhing } \\
\text { movements in a dose- dependent } \\
\text { manner [9]. }\end{array}$ \\
\hline Analgesic & Electric current test in rats & Volts needed as a noxious stimuli & $\begin{array}{l}\text { Definite analgesic action at a dose } \\
\text { of } 200 \mathrm{mg} / \mathrm{kg} \text { of flower extract [48]. }\end{array}$ \\
\hline
\end{tabular}




\begin{tabular}{|c|c|c|c|}
\hline Pharmacologic effect & Model & Measurements & Evidence \\
\hline Anti-tumor effect & $\begin{array}{l}\text { Lung squamous carcinoma cells } \\
\text { (sk- mes-1) }\end{array}$ & $\begin{array}{l}\text { Cell proliferation assay- Mor- } \\
\text { phology test- Cell cycle and apop- } \\
\text { tosis analysis- Western- blotting } \\
\text { analysis- Annexin-V assay }\end{array}$ & $\begin{array}{l}\text { Prevention of SK-MES-1 cells } \\
\text { growth and induction of S phase } \\
\text { arrest. Cactus polysaccharides } \\
\text { cause apoptosis in SK-MES-1 cells } \\
\text { determined by Annexin-V assay. } \\
\text { cactus polysaccharides induced } \\
\text { growth arrest and apoptosis may } \\
\text { be due to the increase of P53 and } \\
\text { phosphatase and tensin homolog } \\
\text { deleted on chromosome ten } \\
\text { (PTEN) protein [90]. }\end{array}$ \\
\hline Hypotensive activity & $\begin{array}{c}\text { Sprague-Dawley rats - NMRI } \\
\text { mice }\end{array}$ & $\begin{array}{c}\text { Mean Arterial Blood Pressure } \\
\text { (MABP)- Toxicology of extract } \\
\text { indicated by the change in the } \\
\text { physical behavior or motor activity } \\
\text { of animals and appearance of } \\
\text { the animal- Tissue Analysis and } \\
\text { Histopathology- Serum Choles- } \\
\text { terol, Glucose, Bilirubin, and Total } \\
\text { Protein Levels }\end{array}$ & $\begin{array}{l}\text { Administration of methanolic } \\
\text { extract of } O D \text { and opuntioside-1 } \\
\text { showed a decrease in the MABP } \\
\text { of rats by three different routes } \\
\text { (intravenous, intraperitoneal, and } \\
\text { oral) of administration is signifi- } \\
\text { cant [76]. }\end{array}$ \\
\hline In-Vitro antimicrobial & $\begin{array}{l}\text { Plate hole diffusion- Agar well } \\
\text { diffusion- Saubouraud dextrose } \\
\text { agar medium (SDA)- cup plate } \\
\text { method }\end{array}$ & $\begin{array}{c}\text { Determine the growth inhibition } \\
\text { of bacteria- Anti-tubercular assay } \\
\text { using Microplate Alamar Blue As- } \\
\text { say (MABA) with the suspension } \\
\text { of Mycobacterium tuberculosis } \\
\text { H37Rv strain }\end{array}$ & $\begin{array}{l}\text { Among the various microorgan- } \\
\text { isms, the aqueous methanolic } \\
\text { extract was more active against } \\
\text { Micrococcus leuteum, Proteus } \\
\text { mirabilis. In the antifungal activity } \\
\text { of the aqueous methanolic extract } \\
\text { shows positive results for all fun- } \\
\text { gus. The antitubercular activities } \\
\text { were compared with standard } \\
\text { drug Rifampicin. The aqueous } \\
\text { methanolic extract was having } \\
\text { more percentage inhibition when } \\
\text { compared to other extracts [91]. }\end{array}$ \\
\hline In-Vitro antimicrobial & $\begin{array}{l}\text { antimicrobial activities of fungi } \\
\text { isolated from surface of } O D \text { eval- } \\
\text { uated against three Gram-positive } \\
\text { bacteria, Bacillus subtilis (UBC } \\
\text { 344), Staphylococcus aureus } \\
\text { (ATCC 43300) and MRSA (ATCC } \\
\text { 33591), two Gram- negative } \\
\text { bacteria, E. coli (UBC 8161), P. } \\
\text { aeruginosa (ATCC 27853) and the } \\
\text { pathogenic fungus C. albicans } \\
\text { (ATCC 90028). }\end{array}$ & $\begin{array}{l}\text { ESIMS and NMR spectroscopic. } \\
\text { minimum inhibitory concentra- } \\
\text { tions (MICs) }\end{array}$ & $\begin{array}{l}\text { Eight endophytic fungi obtained } \\
\text { from } O D \text { surface and all except } \\
\text { one exhibited antibacterial activi- } \\
\text { ties against at least one of the test } \\
\text { bacteria. All extracts were inactive } \\
\text { against C. albicans. The most bio- } \\
\text { active fungus was Fusarium sp. [79] }\end{array}$ \\
\hline In-Vitro antimicrobial & $\begin{array}{c}\text { Extracts from the dried stem of } \\
\text { Opuntia evaluated for antimi- } \\
\text { crobial activities against Bacillus } \\
\text { subtilis, Staphylococcus aureus, } \\
\text { Escherichia coli, and Salmonella } \\
\text { typhi by extraction in non-polar } \\
\text { (petroleum ether and chloroform) } \\
\text { and polar solvents (methanol and } \\
\text { water). }\end{array}$ & $\begin{array}{l}\text { An agar-well diffusion method } \\
\text { was used to determinate the anti- } \\
\text { bacterial activities. }\end{array}$ & $\begin{array}{l}\text { Bacillus subtilis and Staphylo- } \\
\text { coccus aureus were susceptible } \\
\text { to all extracts of Opuntia dillenii. } \\
\text { Ether and chloroform extracts of } \\
\text { O.dilleniiexhibited antimicrobial } \\
\text { activity against Escherichia coli. } \\
\text { Salmonella typhi was resistant to } \\
\text { all of O.dilleniiextracts.[80] }\end{array}$ \\
\hline Hepatoprotective & CCl4-induced liver injury in mice & $\begin{array}{l}\text { Serum ALT and AST activities, } \\
\text { the content of liver GSH and GR, } \\
\text { GST, GSH-Px activities levels, } \\
\text { histopathological evaluations }\end{array}$ & $\begin{array}{l}\text { OD polysaccharides can protect } \\
\text { mice against } \mathrm{CCl} 4 \text { induced hepa- } \\
\text { totoxicity possibly due to its anti- } \\
\text { oxidative capability of strengthen- } \\
\text { ing the GSH system [75]. }\end{array}$ \\
\hline Hepatoprotective & $\begin{array}{l}\text { Cadmium-induced liver injury } \\
\text { in mice }\end{array}$ & $\begin{array}{l}\text { Hepato- histopathological } \\
\text { indicator }\end{array}$ & $\begin{array}{c}\text { Alteration of hepatic- histo- } \\
\text { pathological changes after cadmi- } \\
\text { um treatment reveals the } \\
\text { curative role of } O D \text { in liver injury } \\
\text { [74]. }\end{array}$ \\
\hline
\end{tabular}




\section{Material and Method}

This review is included available data reporting in the literature about morphology, phytochemistry, ethnopharmacological applications and pharmacology of $O D$ until December 11, 2018. For collection of data, scientific databases consisting of PubMed, Science Direct, Scopus, Web of Science, Scirus and Google Scholar were used. The search keywords were Opuntia, Opuntia dillenii (OD), pharmacological properties, antioxidant, anti-inflammatory, neuroprotective, hepato-protective, anti-cancer, Immuno-modulatory, hypotensive, anti-diabetic, chemical composition and their mixture. We also explored the therapeutic potential of $O D$ in the field of ethnophytopharmacology. Finally, about 142 articles from 1972-2018 were found that 91 cases of them were selected for our study. In our study, the inclusion criteria were studies in English, accessibility to full text and articles mentioned pharmacological properties of $O D$ and other genera of Opuntia. The articles that were not in English or the full text was not available, were excluded.

\subsection{Opuntia dillenii (OD)}

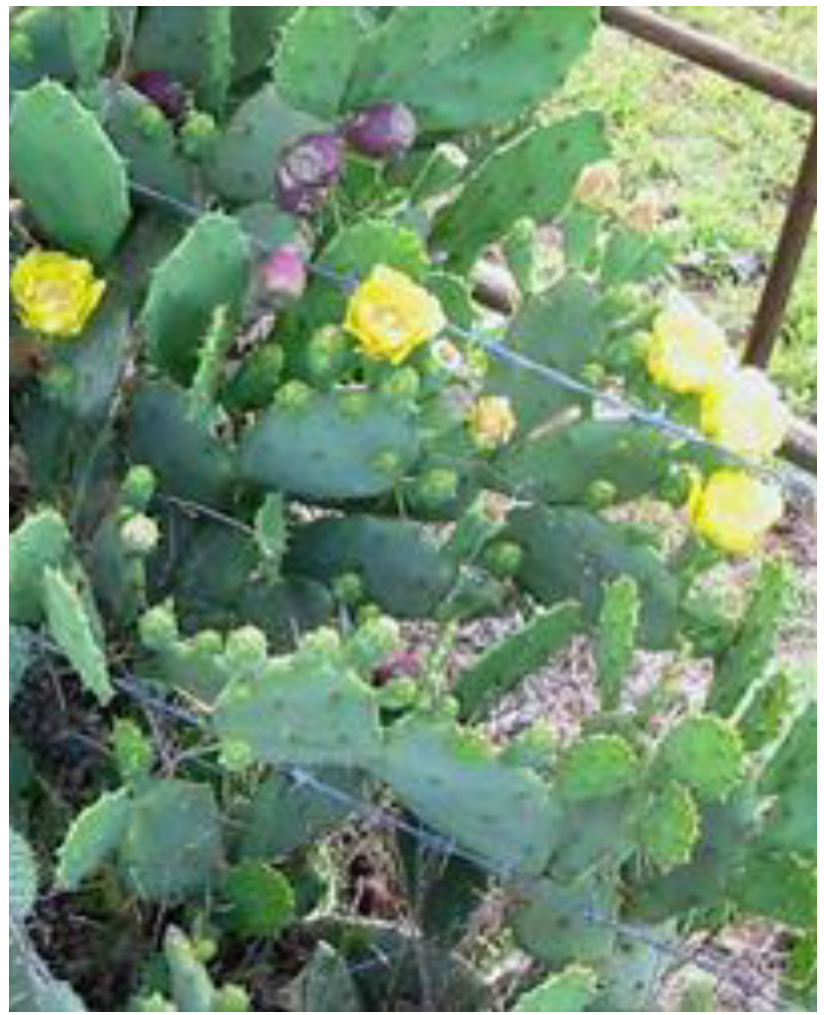

Figure $1 O D$ Photograph by Sheldon Navie

$O D$ is a member of the Cactaceae family (Figure 1), which is found in all temperature zones and has been used as an ornamental plant $[12,15]$. The Cactaceae consists of 130 genera and 1500 species, which have remained largely unexplored for their therapeutic potency $[12,16]$. OD cactus has a specific name: $O D$ (Ker-gawl) Haw. and also called as Australian pest pear, common prickly pear, Dillen's prickly pear, Eltham Indian fig, erect prickly pear, pipestem prickly pear, Gayndah pear, sweet prickly-pear, spiny pest-pear, spiny pest pear, sour prickly pear, sweet prickly pear and prickly pear [17]. It is a plant growing in deserts and semi-desert areas, including tropical and sub-tropical areas like south-eastern parts of North America and east coast of Mexico, the Bermudas, the West Indies and from the north of South America as well, the Gulf Coast of Texas and the south-eastern beaches of Brazil [18-21]. Moreover, this plant is found in around the Mediterranean [16], the Canary Islands, Madagascar and Mauritius, North Yemen, India, Pakistan, the south-eastern parts of Asia and Australia [9, 11, 19, 22-27].

\subsection{Chemical composition}

The betalains a natural pigment with pharmacological properties such as antioxidant, anti- cancer, anti-lipidemic and antimicrobial activity are the most constitute of $O D$. Their biosynthesis is based on the ability of plants to provide betalamic acid which condenses with cyclodopa or amino acids in non-enzymatic reactions [28-30]. The consumption of $O D$ fruits represents an important contribution to the intakes of fiber, ascorbic acid, $\mathrm{Mn}, \mathrm{Cr}$ and total phenolics which makes it a great antioxidant and also a powerful complementary diet (Table 2) [31].

\subsubsection{Cladode}

Kalegowda P et al. showed that mucilage extracted from cladodes of $O D$ (Ker-Gawl) Haw in aqueous medium yields about $6.2 \%$. The neutral sugar composition consisted of arabinose $(38.80 \%)$, rhamnose $(15.70 \%)$, galactose $(33.00 \%)$, xylose $(5.10 \%)$ and glucose $(5.10 \%)$ [32, 33]. Furthermore, some investigations show the isolation of two new a-pyrones, called opuntioside II and opuntioside III, from the cladode and stem of $O D$ extract with about six known compounds together. The structures of these new compounds were determined based on the chemical and physicochemical researches [34].

\subsubsection{Fruit}

In a study conducted by Elena Díaz-Medina et al., differences in chemical compositions between the fruit of $O D$ and Opuntia ficus indica were evaluated. Results showed $O D$ had higher contents of fiber, fat, ash, acidity, ascorbic acid, total phenolics, $\mathrm{Na}, \mathrm{Ca}, \mathrm{Mg}, \mathrm{Mn}$ and $\mathrm{Cr}(\mathrm{p}<0.05)$ and lower values of ${ }^{\circ} \mathrm{Brix}$, proteins, $\mathrm{pH}, \mathrm{K}, \mathrm{Fe}, \mathrm{Zn}$ and $\mathrm{Ni}$ [35]. These studies were not the only researches evaluating chemical composition of this plant. Other studies also had revealed the chemical composition (protein, Brix, moisture, acidity, saccharose, glucose, fructose and minerals), the physical properties (Linear dimensions, density, mass, shrinkage and porosity) and equilibrium properties (sorption isotherms, enthalpy and entropy) of $O D$ fruit. This fruit is a valuable resource for water content, minerals, and acidity. Investigation on another plant of this family named prickly pear has revealed a value of total soluble solids (12-17\%), acidity (0.03-0.12\%), pH (6.0-6.6), 
Table 2 Chemical composition of O.dillenii

\begin{tabular}{|c|c|c|}
\hline plant & part & Chemical composition \\
\hline \multirow{4}{*}{ Opuntia dillenii } & fruit & $\begin{array}{c}\text { fiber, fat, ash, acidity, ascorbic acid, total phenolics, } \mathrm{Na}, \mathrm{Ca}, \mathrm{Mg}, \mathrm{Mn} \\
\text { and } \mathrm{Cr} \text {, }{ }^{\circ} \mathrm{Brix} \text {, proteins, } \mathrm{K}, \mathrm{Fe}, \mathrm{Zn} \text {, and } \mathrm{Ni} \text {. saccharose, glucose, fructose } \\
\text { and minerals, water content. }{ }^{14} \mathrm{C} \text {-labeled betanidin an indole carbox- } \\
\text { ylic acid }\end{array}$ \\
\hline & Seed & $\begin{array}{c}\text { calcium, phosphorus, potassium, magnesium, sodium and zinc.fatty } \\
\text { acids such as linoleic acid, Palmitic acid. }\end{array}$ \\
\hline & Cladode & $\begin{array}{l}\text { neutral sugar composition consisted of arabinose, rhamnose, galac- } \\
\text { tose, xylose, and glucose, two new a-pyrones, called opuntioside II } \\
\text { and opuntioside III. }\end{array}$ \\
\hline & Stem & 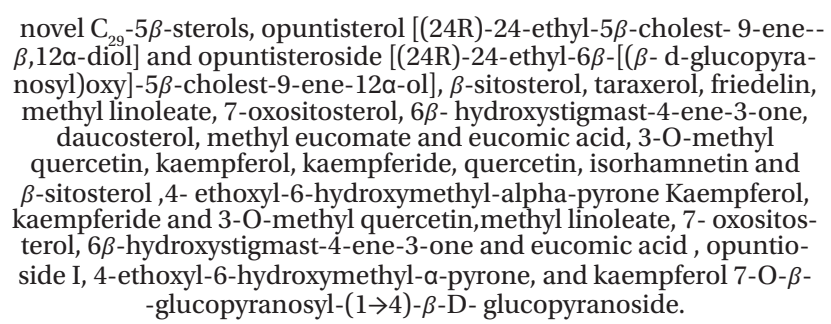 \\
\hline
\end{tabular}

ascorbic acid contents (20-40 mg/100 g fresh weight) nutritional values of energy (172 kJ), vitamin C (14 mg), glucose (7.8 g), fibre ( $1.8 \mathrm{~g})$, protein ( $0.7 \mathrm{~g})$, fats $(0.5 \mathrm{~g})$, potassium (220 mg), magnesium (85 mg), calcium (56 mg) and phosphorous ( $24 \mathrm{mg}$ ) for $100 \mathrm{~g}$ eatable portion. This plant is used in dehydrated areas as an edible product too [44-46]. its revealed that ${ }^{14} \mathrm{C}$-labelled betanidin an indole carboxylic acid is a compound found in the fruits of $O D$ [36].

\subsubsection{Seed}

M. Ramdani et al. reported that the minerals of $O D$ dry seeds consist of: calcium at 408.28; phosphorus at 970.15; potassium at 201.96; magnesium at 240.30; sodium at 18.18 and zinc at $78.26 \mathrm{mg} / 100 \mathrm{~g}$ dry seeds. The seed oil of $O D$ mainly contains fatty acids such as linoleic acid: 79.83\%, Palmitic acid: $13.52 \%$ [37].

\subsubsection{Stem}

The previous investigations also show two novel $\mathrm{C}_{29}-5 \beta$-sterols, opuntisterol[(24R)-24-ethyl- $5 \beta$-choles9 -ene- $6 \beta, 12 \alpha$-diol $]$ and opuntisteroside [(24R)-24-ethyl

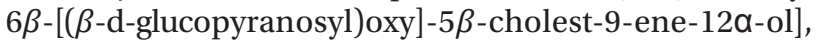
together with nine known compounds, $\beta$-sitosterol, taraxerol, friedelin, methyl linoleate, 7 -oxositosterol, $6 \beta$-hydrox ystigmast-4-ene-3-one, daucosterol, methyl eucomate and eucomic acid, were isolated from the stems of $O D$ collected in Guizhou Province, China [20].

Qiu Yingkun et al. could isolate six compounds from $O D$ stems called 3-O-methyl quercetin, kaempferol, kaempferide, quercetin, isorhamnetin and $\beta$-sitosterol on the basis of the chemical evidence and spectral analysis. In another study, a new compound named 4-ethoxy-6-hydroxymethyl-alpha-pyrone was isolated from the $80 \%$ ethanolic extract of the stems of this plant [38]. Kaemp- ferol, kaempferide and 3-O-methyl quercetin were isolated for the first time from $O D$ stems [39]. Some studies demonstrated that compounds like methyl linoleate, 7 -oxositosterol, $6 \beta$-hydroxystigmast- 4 -ene-3-one and eucomic acid were isolated from the stems of $O D$ for the first time $[40,41]$. Furthermore, investigations obtained three new compounds, opuntioside I, 4-ethoxy-6-hydroxymethyl- $\alpha$-pyrone and kaempferol 7-O- $\beta$-D- glucopyranosyl-$1 \rightarrow 4)-\beta$-D-glucopyranoside, from the stem extract of $O D$. The structures of the new compounds were determined on the basis of chemical and physicochemical evidence [10].

\subsection{Medicinal Uses}

There is considerable evidence of using this plant as medicinal plant in various countries throughout the world, including India [11], Canary Islands [9, 42], Taiwan [43], China [10] where this plant has drawn great attention and some healthy drinks are provided from its extraction too [44-46].

\subsection{Pharmacological properties}

\subsubsection{Immuno-modulatory, Anti-inflammatory activities and analgesic activities}

Many studies have indicated the analgesic and anti-inflammatory effects of the genus Opuntia in many various extract types like fruit extract, lyophilized cladodes or the phytosterols from fruit and stem extracts [47]. It has been reported that this plant presents anti-inflammatory effects. Lyophilized aqueous extract of the fruits of the plant, used in Canarian traditional medicine for gastrointestinal and bronchial troubles, was evaluated for analgesic and anti-inflammatory effects in rats and mice. The $O D$ extract 
(100-400 mg/kg, i.p.) inhibited, in a dose-related way, carrageenan-induced paw edema in rats. A dose-dependent action was obtained against chemical (writhing test) and thermic (hot plate test) stimuli, respectively, with doses of 50 and $100 \mathrm{mg} / \mathrm{kg}$ [9]. In another study, evaluation of the anti-inflammatory and analgesic effects of the alcoholic extracts of flowers, fruits and stems of $O D$ using carrageenan-induced rat paw edema and electrical current tests showed the most anti-inflammatory effect at the dose of $200 \mathrm{mg} / \mathrm{kg}$ of flower extract. Bioassay-guided fractionation of this extract by vacuum liquid chromatography (VLC) followed by Sephadex and paper chromatography showed three flavonoid glycosides i.e. kaempferol 3-O- $\alpha$-arabinoside,isorhamnetin-3-O-glucoside and isorhamnetin-3-O-rutinoside [48]. Siddiqui et al. showed the anti-inflammatory effect of $O D$ cladode methanol extracts using inhibition of arachidonic acid metabolites and cytokines. Their report also described the anti-inflammatory activity of opuntiol and opuntioside for the first time [26]. The other members of this genus such as Opuntia ficus indica and Opuntia humifusa have also been reported to exhibit anti-inflammatory effects [49-53]. Investigation of specific modulation of the immune system by $O D$ polysaccharides in a murine model immunosuppressed by intraperitoneal injection of cyclophosphamide (ip) showed that this plant can potentially enhance the specific immune function of immunosuppressed mice as well as the proliferation of lymphocytes in vitro [78].

\subsubsection{Antioxidant activity}

Yang Q et al. evaluated the antioxidant activity of crude polysaccharides from $O D$ by DPPH assay used response surface methodology (RSM) to optimize the extraction. Their study revealed $O D$ crude polysaccharides had a good antioxidant activity [54]. $\beta$-Sitosterol isolated from $O D$ as the active anti-inflammatory compound seems to be relatively weaker compared with that of hydrocortisone $[25,55]$.

The aqueous ethanolic extract from the fresh stems of $O D$ has potent radical scavenging activity. In this study, three new compounds isolated from $O D$ called opuntioside I, 4-ethoxyl-6-hydroxymethyl-alpha-pyrone and kaempferol 7-O-beta-D-glucopyranosyl-( $1 \rightarrow 4)$-beta-D-glucopyranoside, were evaluated based on the chemical and physicochemical evidence. The radical scavenging effects of principal compounds were examined too [56]. Li H et al., evaluated the antioxidant effect of polysaccharides isolated from $O D$ using DPPH test, hydroxyl radicals and superoxide radical in vitro. Their study showed these acidic polysaccharides demonstrated good antioxidant activity [57]. A purification and fractionation of OD extract isolated several betalains and polyphenol. This process followed by betalainic and phenolic characterization revealed that this plant was a valuable source of bioactive compounds, with a high amount of total betacyanins (16.63 mg beta$\mathrm{nin} / 100 \mathrm{~g}$ fresh fruit) and betaxanthins (7.55 mg indicaxanthin/100 $\mathrm{g}$ fresh fruit) with elevated antioxidant activity [31]. The antioxidant activities in extracts obtained from four cacti (Opuntia species) fruit varieties were investigated. Quercetin, kaempferol, isorhamnetin, ascorbic acid and carotenoids were achieved from these extracts. The varieties with red-skin fruits contained the most ascorbic acid ( $815 \mu \mathrm{g} / \mathrm{g}$ fruits weight) and the yellow-skinned fruits (Opuntia stricta var. stricta) had the most carotenoids $(23.7 \mu \mathrm{g} / \mathrm{g} \mathrm{fw})$. This study also reported the fact that, the antioxidant capacity of cactus fruits can be related to their flavonoid, ascorbic acid and carotenoid contents. The data exhibited that cactus fruits are a precious source of natural antioxidants [58]. Chang et al. evaluated the methanolic extract from betacyanin-free seeds of $O D$ for antioxidant activity. The results showed in three assay systems a higher antioxidant capacity for betacyanin-free seeds of $O D$ than extracts from peel and pulp with betacyanins. The pulp contains more ascorbic acids than peel and seeds did not contain this valuable vitamin. The extracts obtained from the former have the greater antioxidant capacity than the latter because of a higher amount of total phenolic compounds (133.4 versus $91.5 \mathrm{mg} / 100 \mathrm{~g}$ fresh weight) [43]. Antioxidant activity of this plant in aqueous extractions against lipid peroxidation is also reported [59]. Betanin and isobetanin are two compounds with high amounts of $O D$ fruit. It was indicated that these two compounds were considered great free radical scavengers and valuable antioxidant constituted in certain pH levels [60]. It is also suggested that these compounds may be considered as potentially effective bio-molecules for improving human health and preventing disease states [61, 62].

\subsubsection{Anti-tumor activity}

An investigation showed antitumor effects of polysaccharides isolated from this plant on SK- MES-1 cell lines [63]. Amaresh Mishra has mentioned this plant as an anti-cancer plant [64].

\subsubsection{Neuroprotective}

Xianju Huang et al. evaluated neuroprotective and antioxidant effects of Cactus polysaccharides of $O D$ on brain ischemia-reperfusion injury in rats and on the oxidative stress- induced damage in PC12 cells and these compounds isolated from $O D$, were considerable potency for treatment of ischemia and oxidative stress-induced neurodegenerative disease [65]. These results may be due to $O D$ valuable compounds such as flavonoids known as great antioxidants [66-69]. Furthermore, these results are correlated with the investigation of polysaccharides isolated from Opuntia milpa alta on the $\mathrm{H}_{2} \mathrm{O}_{2}$-induced cortex and hippocampal injury [70]. Other studies on the genus's Opuntia have shown neuroprotective effects too [71-73].

\subsubsection{Hepatoprotective activity}

Published pieces of literature also represented hepato-protective effects of this plant. Shah et al. studied the hepatoprotective effect of fruit pulp extracts of this plant on cadmium-induced toxicity in mice. Their results indicated hepato-protective of $O D$ in hepato-histopathological evaluations [74]. Hepatoprotective effect of polysaccharides obtained from this plant also evaluated by $\mathrm{Yu}$ 
NingHua et al. in the mice model of hepatic injury induced by carbon tetrachloride $\left(\mathrm{CCl}_{4}\right)$. Their results showed that OD polysaccharides could significantly reduce serum ALT and AST activities compared to $\mathrm{CCl}_{4}$ group and increase the content of liver GSH, GR, GST and GSH-Px activities in liver-injured mice. $O D$ polysaccharides also could ameliorate the hepatic pathological changes [75].

\subsubsection{Hypotensive activity}

A study conducted by Saleem et al. showed that the meth anolic extracts of $O D$ cladodes and its pure compounds like $\alpha$-pyrone glycoside and opuntioside-I can exert a hypotensive effect in normotensive rats [76]. A review by Talha et al. on the herbal hypotensive compounds has reported $O D$ as a plant containing hypotensive properties [77].

\subsubsection{In-Vitro antimicrobial synergistic and anti-tubercular (Tb) effects}

Investigation of the synergistic antimicrobial and anti-tubercular activities of $O D$ hydro- alcoholic extract conducted by Subal et al. showed the inhibitory effect upon this plant [78].

At Another study done by Ratnaweera et al Endophytic fungi isolated from the sterilized surface of cladodes and flowers of $O D$ by several nutrient media and their antimicrobial activities were evaluated against two Gram-negative and three Gram-positive bacteria and Candida albicans. The results showed that $O D$ harbors several endophytic fungi producing various antimicrobial compounds with selective antibacterial characteristics. It was mentioned that these antimicrobial properties may be due to secondary metabolites produced by these endophytic fungi such as equisetin obtained from the endophytic Fusarium spp isolated from $O D$ [79].

Javeed et al evaluated the Extracts obtained from the dried stem of $O D$ in polar and non-polar based extraction for antimicrobial effects, their results showed that polar extraction of $O D$ exhibits potent antimicrobial effects [80].

\subsubsection{Anti-diabetic effect}

Perfumi and Tacconi investigated the anti-hyperglycemic effect of $O D$ in normoglycemic and alloxan-induced diabetic rabbits and reported a hypoglycemic effect of this plant. Furthermore, they indicated that this effect is due to reducing intestinal absorption of glucose; however, this may not be the only hyperglycemic action of this plant. For example, this plant may contain some insulin-like compound leading to this effect. This fact should be mentioned that in an oral toxicity study of $O D$ extract, rats given doses of up to $50 \mathrm{ml} / \mathrm{kg}$ exhibited no symptoms of toxicity $[42,81]$. Ripe fresh fruit of $O D$ in the Canary Islands is included in folk medicine as an antidiabetic crude drug [82]. zhao et al. evaluated the efficacy of $O D$ tablet (ODT) in type two diabetes mellitus (DM) patients in a fourweek clinical trial. Their results showed that ODT could improve the glycometabolism of DM patients sufficiently and reduce the impairment of renal function in diabetic neuropathy [83]. Investigation of the possible role of $O D$ fruit juice in the treatment of streptozotocin (STZ)-induced diabetes in rats and additionally nutritive value of the $O D$ fruits by Inas $\mathrm{Z}$. A revealed that oral administration of $O D$ juice to diabetic rats improved lipid profile and body weight gain. It also significantly reduced MDA levels and blood glucose as compared with the non-treated diabetic group [84].

\subsubsection{Clinical trials:}

Antioxidant activity of extracts obtained from $O D$ Haw fruit (ODHF) and its active compounds on low-density lipoprotein (LDL) peroxidation by Trolox equivalent antioxidant capacity and oxygen-radical absorbance capacity approaches were in the order of seed $>$ peel $>$ pulp. Reduction of lipid peroxidation in human plasma showed that this plant possesses great antioxidant effects [43].

Zhao et al. evaluated the effect of $O D$ tablet (ODT) in type two diabetes mellitus (DM) patients in a four-week clinical trial. Their results showed that ODT could improve the glycometabolism of DM patients sufficiently and also reduce the impairment of renal function in diabetic neuropathy [83].

Betanin a compound with the high amount in Opuntia species evaluated on myeloperoxidase/nitrite-induced oxidation of human low-density lipoproteins. Their results suggest that betanin scavenges the initiator radical nitrogen dioxide and can also act as a lipoperoxyl radical-scavenger obviously state the antioxidant effect of various organs of $O D[30,85]$.

\section{Conclusion}

$O D$ certainly should be considered as a plant with suitable properties against various diseases (Figure 2). Chiefly nowadays with the great increasing rate of diseases promoted by the lifestyles especially including diabetes and cardiovascular diseases. The adaptation with various environments and great productivity of this plant make it suitable for medicinal researches in order to purify and isolation new pharmacologically valuable compounds with more efficacies in the prevention and treatment of various diseases. In addition to other studies on the genus Opuntia, the pharmacologic properties such as anti-hyperlipidemia, anti-atherosclerotic, anti-inflammatory, anti-diabetic, antiviral, antioxidant and anti-ulcerogenic properties were revealed. Vitamins B1, B2, C, $\beta$ - carotene, E and D3 were observed. The great effectiveness and fewer side effects in comparison to other drugs may be complementary to mention the value of botanic industries and researches revealing the importance of using herbal plants instead of chemical drugs. Unfortunately, this plant is neglected in the sites of origin and found attention at the other regions of the world. At the end we can announce Opuntia genus and especially $O D$ as great genus and plant in the Cactaceae family needing more investigations to obtain valuable botanic compounds in order to promotion of botanic industries as the future of pharmapuncture. 


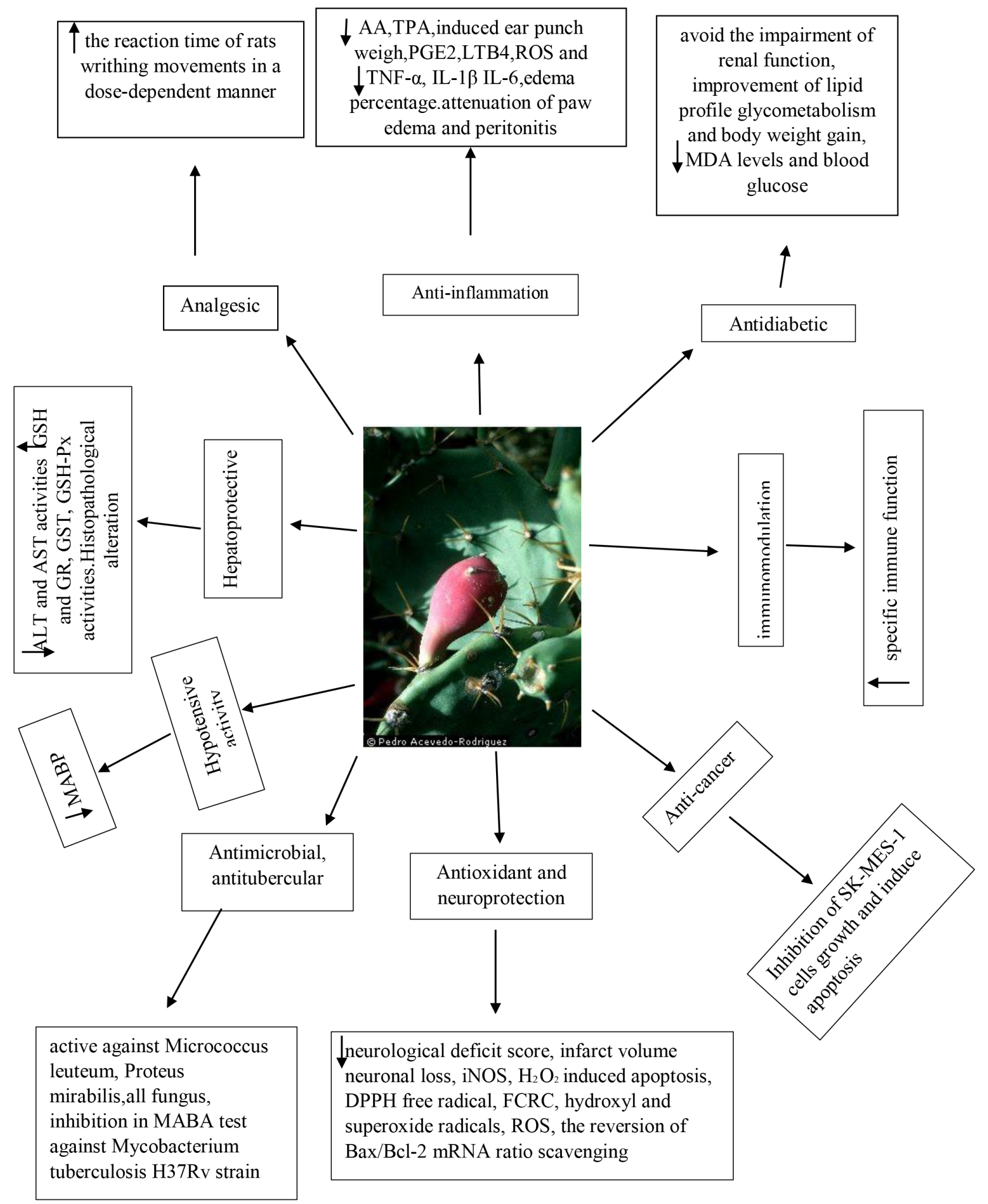

Figure 2 Summarization of $O D$ pharmacologic properties 


\section{References}

1. Petrovska B. Historical review of medicinal plants' usage. Pharmacognosy Reviews. 2012;6(11):1-5.

2. Kelly K. History of medicine. New York: Facts on file; 2009.

3. Kebriaee-zadeh A. Overview of National Drug Policy of Iran. Iranian Journal of Pharmaceutical

Research. 2010;2(3)1-2.

4. Liu Y, et al. Medicinal plants used by Tibetans in Shangri-la, Yunnan, China. Journal of Ethnobiology and Ethnomedicine. 2009;5(1)15.

5. Davidson-Hunt I. Ecological ethnobotany: stumbling toward new practices and paradigms. MASA J. 2000;16:1-13.

6. Thelingwani R, Masimirembwa C. Evaluation of Herbal Medicines: Value Addition to Traditional Medicines Through Metabolism, Pharmacokinetic and Safety Studies. Curr Drug Metab. 2014;15(10):942-52.

7. Scheiber J, et al. Gaining insight into off-target mediated effects of drug candidates with a comprehensive systems chemical biology analysis. J Chem Inf Model. 2009;49(2)308-17.

8. Fosnocht D, Taylor JR, Caravati EM. Emergency department patient knowledge concerning acetaminophen (paracetamol) in over-the-counter and prescription analgesics. Emerg Med J. 2008;25(4):213-6.

9. Loro J, Del Rio I, Perez-Santana L. Preliminary studies of analgesic and anti-inflammatory properties of Opuntia dillenii aqueous extract. Journal of ethnopharmacology. 1999;67(2):213-218.

10. Qiu Y, et al. Constituents with Radical Scavenging Effect from Opuntia dillenii:Structures of New \& alpha; Pyrones and Flavonol Glycoside. Chemical and Pharmaceutical Bulletin. 2002;50(11):1507-1510.

11. Gupta R, et al. Antispermatogenic effect and chemical investigation of Opuntia dillenii. Pharmaceutical biology. 2002;40(6):411-415.

12. Raj V. Plant Opuntia dillenii: A Review on Its Traditional Uses, Phytochemical and Pharmacological Properties. EC Pharmaceutical Science. 2015;1:29-43.

13. Holmes K. Morphological and Ecological Characterization of Opuntia Miller on the Coast of South Carolina, in Clemson University. Clemson University. 2016;2466.

14. Kirtikar KR, B B. Indian Medicinal Plants. International Book Distributors 2; 2006.

15. Halliwell B, et al. Antioxidants and human disease: a general introduction. Nutrition reviews, 1997;55(1):S44.

16. Harlev E, et al. Cancer preventive and curative attributes of plants of the Cactaceae family: a review. Planta Med. 2013;79(9):713-22.

17. Government Q. Weeds of Australia - Biosecurity Queensland Edition. fact sheet 2016 [cited 2017 11/11/2017]; Available from: https://keyserver.lucidcentral.org/weeds/ data/media/Html/opuntia_dillenii.htm.

18. Han YL, et al. Extraction optimization by response surface methodology of mucilage polysaccharide from the peel of Opuntia dillenii haw. fruits and their physicochemical properties. Carbohydrate polymers. 2016;151:381-391.

19. Benson L. The cacti of the United States and Canada.
Stanford (Calif.), Stanford University Press;1982.

20. Scheinvar L. Opuntia dillenii (Ker-Gawl.) Haw. var. reitzii, a new variety from Brazilian Coast. Feddes Repertorium; 1984.

21. Pinkava D, Opuntia M. Flora of North America. Oxford University Press, New York Oxford. 2003;4.

22. MedinaED,RodríguezER,RomeroCD.Chemical characterization of Opuntiadilleniiand Opuntia ficus indica fruits. Food chemistry. 2007;103(1):38-45.

23. Ellenberg H. Opuntia dillenii als problematischer Neophyt im Nordjemen. Flora. 1989;182(1):3-12.

24. Badami R, Thakkar J. Minor Seed Oils XVIII: Examination of Twelve Seed Oils. European Journal of Lipid Science and Technology. 1984;86(4):165-167.

25. Jiang J, et al. Two novel C 29-5 $\beta$-sterols from the stems of Opuntia dillenii. Steroids. 2006;71(13):1073-1077.

26. Siddiqui F, et al. Opuntia dillenii cladode: Opuntiol and opuntioside attenuated cytokines and eicosanoids mediated inflammation. Journal of Ethnopharmacology. 2016;182(Supplement C):221-234.

27. Khare CP. Indian Medicinal Plants: An Illustrated Dictionary. Springer Science \& Business Media. 2007;451452.

28. Schliemann W, Kobayashi N, Strack D. The Decisive Step in Betaxanthin Biosynthesis Is a Spontaneous Reaction 1. Plant Physiology. 1999;119(4):1217-1232.

29. Hempel J, Böhm H. Betaxanthin pattern of hairy roots from Beta vulgaris var. lutea and its alteration by feeding of amino acids. Phytochemistry. 1997;44(5):847-852.

30. Böhm H, Mäck G. Betaxanthin formation and free amino acids in hairy roots of Beta vulgaris var. lutea depending on nutrient medium and glutamate or glutamine feeding. Phytochemistry. 2004;65(10):1361-1368.

31. Betancourt C, et al. Pigment composition and antioxidant capacity of betacyanins and betaxanthins fractions of Opuntia dillenii (Ker Gawl) Haw cactus fruit. Food Research International. 2017;101(Supplement C):173-179.

32. Kalegowda P, Chauhan AS, Nanjaraj Urs SM. Opuntia dillenii (Ker-Gawl) Haw cladode mucilage: Physico-chemical, rheological and functional behavior. Carbohydr Polym. 2017;157:1057-1064.

33. Qiu YK, et al. Study on chemical constituents from Opuntia dillenii. Zhongguo Zhong Yao Za Zhi. 2005;30(23):1824-6.

34. Qiu YK, et al. Two new a-pyrones and other components from the cladodes ofOpuntia dillenii. Archives of Pharmacal Research. 2007;30(6):665-669.

35. Díaz-MedinaE, Rodríguez-Rodríguez EM, DíazC. Chemi calcharacterization of Opuntia dillenii and Opuntia ficus indica fruits. 2007;103:38-45.

36. Sciuto S, Oriente G, Piattelli M. Betanidin glucosylation in opuntia dillenii. Phytochemistry. 1972;11(7):22592262.

37. Ghazi Z, et al. Chemical Composition and Antioxidant Activity of seeds oils and fruit juice of Opuntia Ficus Indica and Opuntia Dillenii from Morocco. Journal of Materials and Environmental Science. 2015;6(8):23382345.

38. Qiu Y, et al. The isolation and identification of a new alpha-pyrone from Opuntia dillenii. Yao xue xue bao Acta 
pharmaceutica Sinica. 2003;38(7):523-525.

39. Qiu Y, et al. A study on chemical constituents of the stems of Opuntia dillenii (Ker-Gawl.) Haw. Journal of Shenyang Pharmaceutical University. 2000;17(4):267-268.

40. Qiu Y. et al. New constituents from the fresh stems of Opuntia dillenii. Journal of Chinese Pharmaceutical Sciences. 2003;12(1):1-5.

41. Trachtenberg S, Mayer AM. Composition and properties of Opuntia ficus-indica mucilage. Phytochemistry. 1981;20(12):2665-2668.

42. Perfumi M, Tacconi R. Antihyperglycemic Effect of Fresh Opuntia dillenii Fruit from Tenerife (Canary Islands). International Journal of Pharmacognosy. 1996;34(1):41-47.

43. Chang SF, Hsieh CL, Yen GC. The protective effect of Opuntia dillenii Haw fruit against low- density lipoprotein peroxidation and its active compounds. Food Chemistry. 2008;106(2):569-575.

44. Li-mei YM. Study of Technology of Opuntia dillenii Haw. Health Drink [J]. FOOD SCIENCE AND TECHNOLOGY. 2000;2:022.

45. Weng P, Wu Z. On Opuntia dillenii Haw. health beverage. Journal of Ningbo University(Natural Science \& Engineering Edition). 2000;13(4):67-70.

46. Meihua Y. Study of Opuntia dillenii Haw healthy drink [J]. THE FOOD INDUSTRY. 2000;2:012.

47. Park EH, Kahng JH, Paek EA. Studies on the pharmacological actions of cactus: Identification of its anti-inflammatory effect. Archives of Pharmacal Research. 1998;21(1):30-34.

48. Ahmed MS, et al. Antiinflammatory flavonoids from Opuntia dillenii (Ker-Gawl) Haw. flowers growing in Egypt. Phytotherapy Research. 2005;19(9):807-809.

49. Cho JY, et al. Radical scavenging and anti-inflammatory activity of extracts from Opuntia humifusa Raf. J Pharm Pharmacol. 2006;58(1):113-9.

50. Matias A, et al. Antioxidant and anti-inflammatory activity of a flavonoid-rich concentrate recovered from Opuntia ficus-indica juice. Food Funct. 2014;5(12):326980.

51. Sharma BR, et al. Anti-nociceptive and anti-inflammatory effects of the methanolic extract of Opuntia humifusa stem. Avicenna J Phytomed. 2017;7(4):366-375.

52. Antunes-Ricardo M, et al. Topical Anti-Inflammatory Effects of Isorhamnetin Glycosides Isolated from Opuntia ficus-indica. BioMed Research International. 2015;9.

53. Jung J, Shin JH. EFFECT OF OPUNTIA FICUS-INDICA EXTRACT ON ANTI- INFLAMMATORY IN MURINE MACROPHAGES. The FASEB Journal. 2010;24(1 Supplement):929.5.

54. Yang Q, et al. Optimum extraction of polysaccharides from Opuntia dillenii and evaluation of its antioxidant activities. Carbohydr Polym. 2013;97(2):736-42.

55. Park EH, et al. An anti-inflammatory principle from cactus. Fitoterapia. 2001;72(3):288-290.

56. Qiu Y, et al. Constituents with radical scavenging effect from Opuntia dillenii: structures of new alpha-pyrones and flavonol glycoside. Chem Pharm Bull (Tokyo). 2002;50(11):1507-10.

57. Li H, et al. Extraction of Opuntia dillenii Haw. Polysac- charides and Their Antioxidant Activities. Molecules. 2016;21(12).

58. Kuti JO. Antioxidant compounds from four Opuntia cactus pear fruit varieties. Food Chemistry. 2004;85(4):527-533.

59. Chen S, Meng H. Study on anti-lipid perioxidation of Opuntia dillemii Haw. Pharmacol Clin Chin Materia Medica. 1997;13(3):36-37.

60. Gliszczyńska-Świgło A, Szymusiak H, Malinowska P. Betanin, the main pigment of red beet: molecular origin of its exceptionally high free radical-scavenging activity. Food additives and contaminants. 2006;23(11):1079-1087.

61. Livrea MA, Tesoriere L. Health benefits and bioactive components of the fruits from Opuntia ficus-indica [L.] Mill. Journal of the Professional Association for cactus Development. 2006;8(1):73-90.

62. Allegra M, Tesoriere L, Livrea MA. Betanin inhibits the myeloperoxidase/nitrite-induced oxidation of human low-density lipoproteins. Free radical research. 2007;41(3):335-341.

63. Li W, et al. Anti-tumor effect of cactus polysaccharides on lung squamous carcinoma cells (SK-MES-1). Afr J Tradit Complement Altern Med. 2014;11(5):99-104.

64. Amaresh M. Preparation of Nutri beverage mix using Opuntia dillenii (cactus fruit); 2016.

65. Huang X, et al. Neuroprotective and Antioxidative Effect of Cactus Polysaccharides In Vivo and In Vitro. Cellular and Molecular Neurobiology. 2009;29(8):1211.

66. Kaur M, Kaur A, Sharma R. Pharmacological actions of opuntia ficus indica: A review; 2012.

67. Pietta PG. Flavonoids as antioxidants. J Nat Prod. 2000;63(7):1035-42.

68. Yeddes N, et al. Comparative Study of Antioxidant Power, Polyphenols, Flavonoids and Betacyanins of the Peel and Pulp of Three Tunisian Opuntia Forms. Antioxidants. 2013;2(2):37.

69. Procházková D, Boušová I, Wilhelmová N. Antioxidant and prooxidant properties of flavonoids. Fitoterapia. 2011;82(4):513-523.

70. Huang $X$, et al. Protection of Cactus Polysaccharide against $\mathrm{H} 2 \mathrm{o} 2$-induced damage in the rat cerebral cortex and hippocampus. Neural Regeneration Research. 2008;3(1):14-18.

71. Dok-Go H, et al. Neuroprotective effects of antioxidative flavonoids, quercetin, (+)-dihydroquercetin and quercetin 3-methyl ether, isolated from Opuntia ficus-indica var. saboten. Brain Research. 2003;965(1):130-136.

72. Ramos RJRS. Evaluation of neuroprotective effects of natural extracts obtained from portuguese agro-food residues; 2012.

73. Osuna-Martínez U, Reyes-EsparzaJ, Rodríguez-FragosoL. Cactus(Opuntiaficus-indica): a review on its antioxidants properties and potential pharmacological use in chronic diseases. Natural Products Chemistry \& Research; 2014.

74. Shah A, et al. Hepatoprotective activity of Opuntia dillenii (Ker Gawl.) Haw. fruit pulp extract against cadmium induced toxicity in mice. 2016;26:1471-1478.

75. Yu N, Zeng F, Rao L. Effect of polysaccharide from Opuntia dillenii Haw on acute liver injury in mice. Chinese 
Journal of Biochemical Pharmaceutics. 2009;30(4):255260.

76. Saleem R, et al. Hypotensive Activity, Toxicology and Histopathology of Opuntioside-I and Methanolic Extract of Opuntia dillenii. Biological and Pharmaceutical Bulletin. 2005;28(10):1844-1851.

77. Talha J, Priyanka M, Akanksha A. Hypertension and herbal plants. Int Res J Pharm. 2011;2(8):26-30.

78. Chefetz I, et al. Inhibition of Aurora-A kinase induces cell cycle arrest in epithelial ovarian cancer stem cells by affecting NFKB pathway. Cell Cycle. 2011;10.

79. Ratnaweera PB, et al. Antimicrobial activities of endophytic fungi obtained from the arid zone invasive plant Opuntia dillenii and the isolation of equisetin, from endophytic Fusarium sp. BMC Complementary and Alternative Medicine. 2015;15(1):220.

80. Umar MI, et al. Polarity-Based Solvents Extraction of Opuntia dillenii and Zingiber officinale for In Vitro Antimicrobial Activities. International Journal of Food Properties. 2013;16(1):114-124.

81. Bever BO, Zahnd G. Plants with oral hypoglycaemic action. Quarterly Journal of Crude Drug Research. 1979;17(3-4):139-196.

82. Atta Ur R, Zaman K. Medicinal plants with hypoglycemic activity. Journal of Ethnopharmacology. 1989;26(1):1-55.

83. Zhao X, et al. Clinical observation of opuntia dillenii tablet in treating type 2 diabetes mellitus. Chinese Journal of Integrated Traditional and Western Medicine. 2002;8(3):215-218.

84. Abdallah IZ. Evaluation of Hypoglycemic Activity of Opuntia dillenii Haw Fruit Juice in Streptozotocin-Induced Diabetic Rats. Egyptian Journal of Hospital Medicine. 2008;33.

85. Allegra M, Tesoriere L, Livrea MA. Betanin inhibits the myeloperoxidase/nitrite-induced oxidation of human low-density lipoproteins. Free Radic Res. 2007;41(3):335-41.

86. Zhao LY, et al. [Immunomodulatory effects of Opuntia dillenii polysaccharides on specific immune function of mice]. Zhong yao cai $=$ Zhongyaocai $=$ Journal of Chinese medicinal materials. 2012;35(1):98-102.

87. Miller NJ, et al. A novel method for measuring antioxidant capacity and its application to monitoring the antioxidant status in premature neonates. Clinical science. 1993;84(4):407-412.

88. Cao G, Sofic E, Prior RL. Antioxidant and prooxidant behavior of flavonoids: structure-activity relationships. Free Radical Biology and Medicine. 1997;22(5):749-760.

89. Tao MH, et al. Hypoglycemic activity of Opuntia dillenii polysaccharides. JOURNAL-HUNAN AGRICULTURAL UNIVERSITY. 2005;31(6):612.

90. Li W, et al. Anti-tumor effect of cactus polysaccharides on lung squamous carcinoma cells (SK- MES-1). African Journal of Traditional, Complementary and Alternative Medicines. 2014;11(5):99-104.

91. Debnath S, Kumar GG, Chandu AN. In-Vitro Antimicrobial Synergistic and Anti-Tb. Research Journal of Pharmacognosy and Phytochemistry. 2011;3(2):67-71. 